\title{
Ottoman Geography - an Article by Franz Taeschner and an Analysis of the Transition from Eastern Scientific Tradition to European Scientific Mentalty
}

\section{Franz Taeschner'in Osmanlılarda Coğrafya Makalaesi ve Doğu İlim Geleneğinden Batı İlim Zihniyetine Geçiş Sürecinin Tahlili}

\author{
Osman ÖZKUL ${ }^{1} \oplus$, Nadir ÇOMAK ${ }^{2} \odot$ \\ ${ }^{1}$ Sakarya University, Faculty of Arts and Sciences, Department of Sociology, Sakarya, Turkey \\ ${ }^{2}$ Medeniyet University, Istanbul, Turkey
}

ORCID: O.Ö. 0000-0002-0418-7007; N.Ç. 0000-0001-5047-3007

\begin{abstract}
This paper attempts to make a contrastive analysis of history via an article by German orientalist Taeschner (1888-1967) in which the mentality of Eastern geography, that of the Ottomans in particular, was investigated and discussed in detail. The article being analyzed in this paper was once taught as a textbook at Westfalia-Wilhelm University (1922) in Münster, Germany. Only four years later, it was published under the name of Ottoman Geography on pages 271 through 314 in the second volume of Journal of Turkology after it had been translated by Hamid Sami. All books with a great impact on medieval Ottoman geographers are compared with a critical approach in the article by Taeschner, where not only the copies of the books in Europe but also those of the books in Ottoman libraries are introduced to the reader. Furthermore, it attempts to explain the change observed in the orientalist science and geography mentality based upon the similarities and differences between these books. Finally, Taeschner goes on to talk in this article about how the mentality of European science in the $18^{\text {th }}$ and $19^{\text {th }}$ centuries affected Ottoman science mentality and discusses the books through which this effect was achieved.
\end{abstract}

Keywords: Ottoman Geography, Franz Taeschner, Eastern and Western Geography

Öz

Bu çalışmanın konusu, Alman oryantalist Taeschner'in genel olarak Doğu ve özel olarak Osmanlı Coğrafyacılığı ile Batı Coğrafyacılığı zihniyetini karşılaştırdığı makalesinden yola çıkarak, bir analiz yapmaktır. Çalışmaya konu olan metin Prof. Franz Taeschner (1888-1967) tarafından 1922 senesinde Almanya'nın Münster şehrinde Westfalia-Wilhelm Üniversitesinde ders örneği olarak okutulmuştur. Bu metin daha sonra 1926 senesinde Türkiyat Mecmuası, II. Cild, 271314. sayfalarında Hâmid Sadî tarafından tercüme edilerek Osmanlılar'da Coğrafya adıyla yayınlanmıştır. Ancak söz konusu makale, bu isme rağmen, genel anlamda Doğu Coğrafya zihniyetini temsil eden belli başı eserleri de tahlil etmekte, Şark coğrafyası hakkında içerik bakımından ayrıntılı bir analiz sunmaktadır. Bunun yanında, Ortaçağ'da Osmanlı coğrafyacılarını etkileyen önemli eserlerin analizini ve karşılaştırmalı bir tahlilini yapmaktadır. Daha sonra, birbirleri ile benzerliklerini ve etkilendikleri konuları belirlemektedir. Ayrıca bu eserlerin Avrupa ve Osmanlı kütüphanelerindeki nüshalarını tanıtmaktadır. Daha önemlisi şark bilim ve coğrafya zihniyetinin geçirdiği değişimi bu eserler arasındaki benzerlikler ve farklııklardan hareketle açıklamaktadır. Daha sonra da 18. ve 19. Asırdaki Osmanlı bilim zihniyetinin nasıl ve hangi eserlerden etkilediğini analiz etmektedir. Tarih coğrafya ve edebiyat alanındaki Batı tesirinin bilim zihniyetinde nasıl tezahür ettiğini anlatan Taeschner, özellikle bu konuda coğrafi eserlerin önemine vurgu yapmaktadır. Eserin Almanca'dan Osmanlı Türkçesine tercümesini yapan, Hamid Sadi de bazı konularda eklemeler ve düzeltmeler yapmaktadır.

Anahtar kelimeler: Osmanlı Coğrafyacılığı, Franz Taeschner, Doğu ve Batı Coğrafyacılığı

Submitted/Başvuru: 25.02.2019 • Revision Requested/Revizyon Talebi: 11.06.2019 • Last Revision Received/Son Revizyon: 12.06.2019 • Accepted/Kabul: 17.06.2019 • Published Online/Online Yayın: 10.09.2019 


\section{INTRODUCTION}

Franz Taeschner was born in Reichenhall, Germany on September 8, 1888. After his secondary education in Berlin, he studied oriental languages and history at Bonn, Munich, Erlangen and Kiel Universities from 1908-1909 respectively. Here he learned Arabic, Persian and Turkish. Kiel University gave a doctoral dissertation in 1912 under the direction of Georg Jacob on Kazvînî's Acâibu'l-mahlûkat in Arabic philology. In the same year he was assigned to the Oriental Studies seminary at the University of Hamburg. After that he continued his studies in Paris and London. After working with Rudolf Tschudi for a while, he was assigned to the Palestinian side as a Turkish translator in World War I.

When the Turkish Palestinian front was dissolved, Taeschner was captured by the British and it wasn't until the end of 1919 that he could return to Germany through Egypt. In 1922, Münster University presented the dissertation prepared by Evliya Çelebi on the topography of the Ottoman Anatolus during his time and work. He went to Istanbul several times in the 1920s, and to Cairo and Jerusalem in 1930-1931. In 1929 he earned the title of professor at the University of Münster (fahrî). In 1935 he was appointed professor of orientalism at the University of Münster in place of Anton Baumstark, and in 1942, he was chaired by the Chairman of the Oriental Institute. After the institute buildings were destroyed in a bombardment towards the end of the war, he lectured his students for a while at his own home. Until his retirement in 1957 he was the director of the institute in Münster. Since 1956 he has headed the Germany-Turkey Friendship Association in Münster. On November 11, 1967, after a long illness, he died at his home in Münster.

Taeschner was a teacher who had a compromising character and was loved by his students and colleagues. He traveled frequently to the countries he was working on and went on field investigations. For example, along with with Paul Wittek in 1927, he toured Western Anatolia, specifically Iznik and Bursa, where early Ottoman structures and books were explored and published in two articles. The scientific areas pioneered by Taeschner include the historical geography of Anatolia, Ottoman geographical literature, cultural history and fütüvvet (Akhizm) history. According to Gabriel Baer, Taeschner was also a superior authority on medieval poets. The history of religions contains other curious issues related to the art history of the Ottomans and Persians. In a 1944 article entitled Der Islam im Banne des Nationalismus der Zwischenweltkriegszeit, he was interested in the development of modernity in Muslim countries.
The article also examines whether the secularization process in Turkey has influences and parallels in other Middle Eastern countries. Taeschner also proposed a new transcription, seeing the translation of Arabic letters into Latin letters as a problem. Carl Brockelmann, together with August Fischer and Wilhelm Heffenning, created the system used today in Germany.

In addition to the text being taught and being the topic of lectures at university, the names of the 9 works by Franz Taeschner are also mentioned in the $39^{\text {th }}$ edition of the Diyanet Islam Encyclopedia written by Reindl Kiel. Apart from these, Mahmut Ak (2004), who made a wider study on Ottoman geography works, mentions more than 9 different works belonging to Taeschner in Ottoman Geography Works.

As can be understood from this brief biographical information, Franz Taeschner is a German orientalist who made very important contributions to the social history of the Ottomans. The Ottoman Empire, the Futbolname and its elements have been evaluated in many respects; especially the Ahi Organization and Futuvvez. However, he has also done valuable work on the Islamic world, the Middle Ages, Iran, Ottoman resources and Turkish culture. Furthermore, he has also worked on Anatolian geography and the road system of this region. Das Anatolische Wegenetz Nach Osmanischen Quellen is one of the most important pieces of research on this subject. One of the studies published in 1926, The Roads of Anatolia and the Relation with the Cihan Relation in Various Periods (Çetin, 2014), is worth studying.

Taeschner has made many studies on the Islamic world and Ottoman geography. He refers to geographical works belonging to the Ottoman period in the article titled Ottoman Geography which is one of the first significant works about geographical works and their characteristics written in the Ottoman period. In the $20^{\text {th }}$ century Adnan Adivar made an extensive study on Ottoman Geographers in his book Science in Ottoman Turks. In this work Adıvar, while criticizing Taeschner in some respects, uses his work as one of his major sources. Ekmeleddin Ihsanoglu published works on the first translated works from the West in the light of the new information.

\section{EASTERN AND WESTERN SCIENTIFIC MENTALITIES REGARDING OTTOMAN GEOGRAPHY}

While works written on Ottoman geography are not absolutely distinct from one another in terms of subject matter, they can still be categorized into three groups: scientific, practical 
and itinerary. Knowledge of location was introduced to Ottoman Turks on the path to mathematics in the form of astronomy and geography through the influence of the Samarkand School. The Samarkand Observatory, established by Kadizade-i Rumi, is known to have had a great impact on Ottoman scientists, because scientists like Ali Kuşçu and his grandson Mahmud Miri Çelebi were either educated there or were very much influenced by this monument in producing their works. Ali Kuşçu greatly influenced other authors with the annotations he added in his works on mathematics and astronomy, Risale fi'l Hey'et, er-Risaletü'l Muhammediyye and Zic-i Uluğ Bey, thus making great contributions to the development of Ottoman geography in the $15^{\text {th }}$ century (Ak, 1993, p. 62).

Of all the books written on Ottoman geography, the first to mention that the Earth was flat was Wondrous Creatures, written by Zekeriya el-Kazvini in the $13^{\text {th }}$ century and published under the name of Rükneddin Ahmet. Taeschner considers this to be the first work written on Ottoman geography, though its content and the information it provides has been subjected to many speculations up to today. Therefore, according to Taeschner (1926, p. 271), the first geographical book written about the Ottomans was not that of Kazvini, rather the book by Ali b. Abdurrahman, Wondrous Creatures, following the conquest of Edirne. This book was translated by Yazıcıoğlu Ahmet Bican from Gallipoli. However, Adıvar argues that such finalist books, which were written with a mediaeval finalist approach, should not be considered as geographical works (Adivar, 1982, p. 2829). The book by Ali b. Abdurrahman, who not only made use of his observations in writing his book but also based it on the books by previous authors, Kazvini, in particular, is of a cosmographic and encyclopaedical nature. It was published in two separate sections, where the skies, stars, seas, rivers and mountains, cities, fortresses and their residents are mentioned as well as subject matters like the creation of the universe (Ak, 1993, p. 63).

In one of his articles, Cevdet Türkay emphasizes that the book by Ali bin Abdurahman, called Geography in the Ottoman Empire, is very important in four different aspects. Firstly, it was the first work on Ottoman geography. Secondly, it was written in the plain Turkish spoken in the $14^{\text {th }}$ century. Thirdly, it was the first work with a copyright. Finally, it was dissimilar to Wondrous Creatures. Türkay relates in his article that Taeschner did not mention this book simply because he had not come across it (Türkay, 1959, p. 7). Nevertheless, according to a postscript by the translator, Taeschner had an opportunity to investigate this book during one of his visits to Istanbul.
According to Adivar, the $16^{\text {th }}$ century was a period in which the Ottoman works were translated and the materials to meet the daily needs were collected. Only a few monographic works were written during this period. Incidentally, the expanding boundaries of the Ottoman Empire and the increasing number of conquests helped marine geography gain even more importance. During this century, the Ottoman Navy had reached as far as the Atlantic Ocean on one side and the Indian Ocean on the other, not to mention the Ottoman Corsairs. It was during such occasions that two Turkish admirals produced books on geography, one of them Piri reis and the other Seydi Ali Reis (Adivar, 1982, p. 74).

According to the narratives of Evliya Çelebi, who spent many years with his uncle Kemal Reis, he extended his knowledge of the sea and navigation. He also learned a great deal about the Aegean and Mediterranean seas thanks to his expeditions, during which he served as a commander. On one hand, he made use of Portuguese and Italian charts, as well as his contemporary geographical works. On the other hand, he took traditional information from Turkish navigation into account and added his own observations. He authored Kitab- Bahriye (Book of the Navy), in both prose and verse forms, and rewrote his work in 1526, extending it even further (Evliya Çelebi, 2008, p. 29). The work itself is of great importance for the Mediterranean region considering the era in which it was produced.

Taeschner emphasizes the following while he narrates the features of Ottoman geographical Works: books on Ottoman geography were usually written in the field of "historical geography". Due to this characteristic, these works were filled with old information with reference to Primitive and Medieval Ages. Ottoman geographers were not concerned with natural and mathematical elements of science; rather, they were concerned with regional geography and topography. On the other hand, consistent with common characteristics of the Medieval Age, they were of a narrative and literary nature. These books were mainly concerned with whether earlier books were consistent with the phenomena of the day, rather than focusing on what was happening on Earth (Taeschner, 1926, p. 273-274). Therefore, the trend was such that new information was to be added to old information even if it lacked relevance. General descriptions and definitions of a speculative nature were of great importance. It is this tradition of Ottoman geographical works that continued until the Western influences started to emerge. 


\section{THE TRANSITION FROM THE MEDIEVAL TO THE NEW AGE IN OTTOMAN GEOGRAPHY}

Taeschner, in his article also classified Ottoman geographical books, considering the age when they were produced, and categorizing them into three main topics according to their specialty and content. According to Taeschner, (1926, p. 275), while these topics may sometimes overlap, they still have their own boundaries.

1. Books of scientific geography: These are also split into three groups: a) a small number of mathematical works; b) books on astronomy; c) books written solely for scientific needs

2. Books serving practical needs, which contain practical information not only regarding the Empire but also about the daily life of the public.

3. Travel books: Taeschner also speaks of books called Sefaretname, written by Ottoman envoys (of which 16 are mentioned in this article). These are named towards the end of the article along with details about them.

When narrating the Ottoman geographers of the Ottoman Classical Age, Taeschner speaks of the Works of Yazicioglu Ahmet Bican, Ali bin Abdurrahman, Sipahizade, Ali Kuşçu, Kemal Reis and Seydi Ali Reis. He offers a detailed library of information for each of these authors. When narrating the characteristics and mentality of these books, however, he claims "We come across no significant book or books that could be considered the outcome of their own efforts, even among the books written during the rise of the Ottoman Empire". As for scientific geography, it remained rather poor. What Ottoman Turks were mostly concerned with regarding science was determining the physical geography of certain cities, inasmuch as practical books were of more significance during this era. For instance, the books containing road descriptions, which were meant to serve their practical needs, or issues concerning political division and statistics took up a large part of such books (Taeshcner, 1926, p. 282 -283).

El Muhit (The Ocean), by Seydi Ali Reis contains comprehensive information about the Indian Ocean and South Asian Coasts, and so is of great importance. Ottoman scientists only became partly familiar with geographical discoveries being made across the world when a book was translated into Ottoman Turkish under the auspices of Sultan Murad III. This book, written by an anonymous writer, is known as Tarih-i Hind-i Garbi (History of The West Indies), and it has reached the present day under different names. The oldest known copy of this book was presented to the Sultan Murad III in 1583. Written under the influence of both western and eastern works, this book is split into three parts, including Ottoman lands, the size of the Atlantic Ocean and the discoveries that were made from 1492 through 1552, respectively (Ak, 1993, p. 64).

According to Taeschner (1926, p. 285), the general characteristic of the Ottoman Geographers was such that once they had many books translated into their language, they became gradually involved in producing works on cosmography and public geography as well, while also adhering to the earlier books written during the Medieval Age. Apart from Bahriye (The Navy), by Piri Reis, the way Ottoman authors wrote their works was heavily influenced by the classics of the Medieval Age. A good example of this is Künhü'l Ahbar by Mustafa Ali, who was a Suleymaniya timekeeper during the reign of Kanuni.

A good example of the books detailing a new cosmogony system is Künhü'l Ahbar (The Essence of News), by Müverrih Ali (1599). The writer was a muvakkit (a person responsible for determining the time for Muslim call to prayer), during the reign of Solomon the Magnificent I, and had a wealth of experience in producing works on astronomy and mathematics.

The author narrates in this book all the phases the universe passed through from the time it was born until this book was written with a completely new cosmogony, in contrast to the previously held cosmography. He also speaks of geography in a supplemental method in the very first chapter of this great book. Making use of different resources, he makes a summary of old geography. Taeschner (1926, p. 286) argues that the information given by Ali is very compact with no inessential details considering that it was the first time geography was written concisely within a historical framework.

According to Taeschner (1926, p. 287), we can speak of Menazıru'l Avâlim (Views of the World), written by Mehmed Âş1k, as the last example of those books written on Medieval geography in the East. This work is of great use in that it represents the transition from Medieval Age to Modern times thanks to the significant information it contains, while also conserving its originality. Even so, it is an anachronistic book which fails to make a clear distinction between events that occurred in different times. However, it is still an amazing piece of work of the East.

With regard to Taeschner's comments concerning the history of science, the East and West were nearly on the same civilizational level. However, the way they developed had been 
very dissimilar since the beginning of the Modern Age even though they could have interacted with no problems. In the opinion of Taeschner, the East failed to keep up with the West at a time when intellectual reforms were occurring all across Europe and a rapid progression was taking place. Given these developments, the East began to appreciate the West less and less, thus making a healthy interaction between two poles even less likely. In this context, great works of East, such as Menazıru'l Avâlim (Views of the World), remained rather traditional. At a time when European works were gaining recognition in the East, Eastern people were deprived of sufficient scientific background, which could, in fact, have enabled a proper interaction with the West (Taeschner, 1926, p. 293).

The author, when narrating the process of how Ottomans fell behind the West in the field of science, portrays them as selfindulgent people who made use of earlier works of the Islamic civilizations but neglected to make sufficient contributions to them, which resulted in a failure to improve them. During the rise of the Ottoman Empire, Turks, who were the true heirs of Islam, adopted a successful offensive policy against the West, and so managed to survive the traditional way of Eastern life. However, this caused them to remain oblivious to what was happening across Europe and remain immune to European influence. Nevertheless, once they had lost their strength, they realized that it was no longer possible to continue in this way. In the meantime, the civilizational superiority gained by the West had already started to influence the Ottomans. Taeschner admits that Ottoman geographers soon became aware of scientific studies in the West. However, he says that the adoption of the term "The New World" takes a long time.

According to Taeschner, despite their pride at the time, Ottomans were rapidly learning of the western geographical discoveries made in the new frontiers. Nonetheless, the concept of Novus Mundus (The New World), took a great deal of time to appear in Ottoman works or books written on geography. It was only during the $17^{\text {th }}$ century that Ottoman works began to be influenced by European science, which astonished intellectual society.

In speaking of the famous book Cihannüma by Kâtip Çelebi, where the Ottomans introduced geographical studies of the West, Taeschner argues that the word "Kosmoroma" is equal to the word "Cihannuma" (Taeschner, 1926, p. 294). Narrating the writing process of this work at length, the author talks about the purpose of Kâtip Çelebi, as well as those who he was inspired by and benefited from. To his way of thinking, Kâtip Çelebi reorganized all of the geographical information in compliance with the Western viewpoint, while also mentioning the astronomical and mathematical works of Europeans absolutely consistent with old Eastern principles at the very beginning of his book Cihannüma.

In fact that, Kâtip Çelebi does not have his own research in the field of astronomy and riyazi geography. Because, as seen in all his works, he is not an expert scholar, but an eclectic writer. The importance of Cihannüma is that it includes old oriental and new western works. After all, he never meant to produce a selfcontained work. His real purpose was to write a book with which he could teach Ottomans the existing understanding of geography of his time (Taeschner, 1926, p. 298).

In analyzing Cihannüma, which was printed by Ibrahim Müteferrika, Taeschner assumes that an extension might have been written by another author, and that postscripts by other authors might have been added afterwards. Furthermore, he argues that this only makes Cihannüma even more controversial as far as originality of this book is concerned, and that determining where this book lies among other books on geography seems to matter even more for the history of geographical works (Taeschner, 1926, p. 299).

Concluding that there is a clear European influence in the construction of Cihannüma, Taeschner refers to the fact that this book has as much value for philological aspects value as it has for geographical ones by commenting as such. Considering the benefits we can get from this book, which is not hugely important in terms of the science of geography per se, it is very important for the history of the science of geography. We must also admit that Kâtip Çelebi was as much preoccupied with geography as was Mehmed Âşık, and that he was able to obtain and improve information about Medieval Age Geographers thanks to his remarkable intelligence and observations. However, these issues should be investigated comprehensively.

According to Taeschner (1926, p. 300), Cihannüma is the first and ultimate systematic geographical work to have been produced by Ottoman authors across Ottoman territories. Although Kâtip Çelebi did not make personal travels to gather geographical information unlike Âşık Çelebi, he still wandered across Ottoman territories and participated in numerous campaigns. Moreover, he easily accessed official information due to being a civil-servant. This being the case, the details he provided are of great importance as long as they were clearly distinguished from others. 
The most famous name of the $17^{\text {th }}$ century Ottoman Empire was without a doubt Evliya Çelebi, whose travels across most of the Ottoman territories continued for more than 40 years. In his tenvolume-work Seyahatname, he offers extensive information about the geography, politics, economic situation, folkloric structure, bathrooms and buildings of not only the places he saw but also of the places he was not able to see as well. To sum up, he generously provided us with cultural and practical information (Karaörs, 1992, p. 10).

Taeschner also elaborately speaks of Evliya Çelebi in detail, whose book Taeschner Thought, not only consists of excellent texts but is also a privileged one in terms of its richness in historical, geographical and practical information and the crystal-clear details it provides. In his travel book, this unyielding, distinctive man gives details and provides extremely clear descriptions, albeit at times perhaps overly idealistic. This piece of work is basically a book of memories, and so has great importance for narrating the events that occurred during his era. It is a matchless masterpiece of all eastern works with regard to comprehending the status of the Ottoman Empire and its people. It had long been appreciated that this work was precious for cultural history thanks to the amazing details it holds. Evliya Çelebi travelled as far as Iran, Caucasus, Bagdad, Syria, Mecca, Egypt, Southern Russia, Wallachia, Bosnia, Hungary and even Germany either as a Muslim religious leader or sometimes as a private scribe or courier of famous governors (Taeschner, 1926, p. 303).

While Evliya Çelebi, who was very well-educated, benefitted from a good amount of resources, one might get the impression that he composed his work without being influenced by anyone. The events he recounts are unique in that what he speaks of in his writings are very consistent with daily life, an approach we do not come across in other eastern works. These writings require watchfulness and long, enjoyable travels. However, as one closely investigates them, it becomes obvious that some parts of this work were actually taken from other resources. Furthermore, it is also possible to come across historical information based on his observations in some of his details. We conclude that this work literally quoted geographical information, as well as information about various locations of the Ottoman Empire, from other resources. However, the influence of other geographers is only vaguely observed (Taeschner, 1926, p. 304).

Taeschner argued that Evliya Çelebi was unaware of Cihannuma by Kâtip Çelebi, though it was highly likely that he had come across Menazıru'l Avâlim (Views of the World). Only in this way could Evliya Çelebi have known about the accounts of medieval geographers he relates in his book. In the opinion of Taeschner, it is possible that Evliya Çelebi made use of several other resources in writing his well-known book Seyahatname (The Book of Travels), though chances for such a thing to have happened may look slim. However, based on the matchless descriptions he made of the places through which he travelled, we could assume that Seyahatname is a self-contained book of distinctive significance when compared to the books by Kâtip Çelebi and Mehmed Âşık.

On the other hand, we do not have sufficient evidence to claim that Evliya Çelebi made use of resources apart from the abovementioned western ones. Also, we often come across exaggerated and controversial pieces of information in his book, though he does not base this information on concrete evidence. Despite all its flaws, we should focus on benefiting from the content of this book considering how significant and invaluable it is. It is possible to make use of this book for serous studies; however, this would only be plausible after it has been published in the light of scientific rules and criteria (Taeschner, 1926, p. 305).

If we were to make a comparison between works written on geography, Taeschner claimed, Seyahatname by Evliya Çelebi would stand out as the largest and most beneficial work on physical geography of the Ottoman Empire. Just as the book by Mehmed Aşık was the last of the scientific works based on mediaeval traditions, so too the book by Evliya Çelebi can be considered as the last to be produced by eastern geographers. The influence of European works in the following ages was so great that there was an end to home-grown scientific products in almost every field. Given that sole historiography is closely related to the continuance of the government, it went no further than serving as an imitator as long as the Ottoman Empire retained its independence and orientalism (Taeschner, 1926, p. 306).

This article by Franz Taeschner, who informs us about the geography books written following the classical eara and their subject matters, as well as their authors and distinctive features, is one of the first ones to have been written in this area and aims to shed light on and evaluate the works written during his era and earlier ones. This article is also of rare significance in that Taeschner takes care in emphasizing the shortcomings of these works and draws attention to the methods used by their authors. According to Taeschner, the reason why geographical studies conducted in the Ottoman Empire up until his time had not been benefited from as sufficiently as desired was that orientalists were not sufficiently interested in Ottoman works, and that the 
Turks themselves neglected to appreciate the works produced by their own scientists (Göçer, 2006, p. 48).

\section{OTTOMAN GEOGRAPHY UNDER THE INFLUENCE OF THE WEST}

Before we discuss the works written on Ottoman geography under the influence of the west, it would make sense to mention one of the comments by Taeschner, which claims that none of the works written on geography in the $18^{\text {th }}$ century is comparable to those written by Mehmed Âşık, Kâtip Çelebi and Evliya Çelebi. However, a small number of them could be regarded as genuine oriental works, the most important of which is known as Hadikatü'l Cevami (Garden of the Mosques), written by Hac1 Ismail-zade Hafız Hüseyin Efendi. This very useful work is about the description and construction of geographers in Istanbul. The most comprehensive of such works, in which the journey of pilgrimage from Istanbul to Mecca is narrated, is Menastku'l Hacc (Rituals of Pilgrimage), written by Mehmed Edib. These kinds of books primarily focus on the special places to be visited during the pilgrimage as well as the customary practises concerning its fulfilment. As was done in the book by Mehmed Edib, guidance is provided in these books (which are very much like travel books), for prospective pilgrims by giving them information about the special places to be visited in some locations (Taeschner, 1926, p. 307).

Taeschner emphasizes that a new approach began to arise in the $18^{\text {th }}$ century following these classic oriental geographers. The most remarkable characteristic of this era was that the authors concerned with geography had totally gravitated towards Europe. In earlier centuries, Ottoman geographers were involved in translating medieval works into Turkish, and now they were translating European works, albeit indiscriminately. The first product of these vigorous efforts is the translation of Atlas Minor by Kâtip Çelebi. Most of the other books translated concerned Europe and America (Taeschner, 1926, p. 308).

As for the $18^{\text {th }}$ century, we can witness even more recent works on geography fueled by western books. One of these books, known as Icmal-i Ahval-i Avrupa (A Summary of Conditions in Europe), attracts a great deal of attention due to discussing particularly European countries, though neither the author nor the translator is yet known (Özkul, 2009, p. 102). Another book was written on Moldavia and Wallachia by Ibrahim from Bartın. It is unfortunate that the $18^{\text {th }}$ century failed to raise as distinguished an author as Kâtip Çelebi, or as famous a traveller as Evliya Çelebi, or even as good a translator as Ebu Bekir
Behram from Damascus. However, it was through such vigorous efforts of translation that the $18^{\text {th }}$ century became the era when Ottoman geography reached a peak (Orhonlu, 1964, p. 15).

While the books produced in this era were influenced by the West, they also have characteristics of a transition period. A very small number of original books were written on geography in the Ottoman Empire in this predominantly translation works era; rather, travel books or embassy reports were being recorded at this time. Any authors aiming to produce books were heavily gravitating towards the West. Europe and developments there were the main concern of not just the geography books written by the Ottomans but also of travel books. The embassy reports written by the ambassador groups who were sent to Europe by the Ottoman Empire are believed to have played a crucial role. Most of these embassy reports are considered have characteristics of history books rather than of geography books. Therefore, most of these embassy reports are of great value and use in that they talk about the disputes between states and contain some very important documents as well as being priceless resources as far as the history of diplomacy is concerned. Taeschner refers in his article to 16 embassy reports and introduces them briefly (Taeschner, 1926, p. 310-312).

In which fields were Ottoman intellectuals largely influenced by Europe? It was scientific books that were mostly exposed to the overwhelming impacts of the superiority of European. In particular, geography books in Ottoman Turkey, which were still far from being mature, were already being written under the heavy influence of foreign resources. As soon as Ottoman scientists were introduced to European science, they began to predominantly assume that Europeans were producing considerably better works. It must have been this viewpoint that strongly restrained the productive capacity of Ottoman scientists, which seems to explain why Kâtip Çelebi failed to be as prolific an author as he could have been with his amazing capacity. It was only Evliya Çelebi, who made an exception by staying away from such influences and produced an original travel book (Taeschner, 1926, p. 272).

\section{THE INFLUENCE OF EUROPE ON OTTOMAN GEOGRAPHY IN THE $19^{\text {th }}$ CENTURY}

The $19^{\text {th }}$ century had a tendency to be content with translations of western books and sources rather than produce original books on geography. As was aforementioned, Sefâretnâmes are texts written by envoys about their travels and impressions. One such book was written in French during the resign of Sultan Selim III 
in the $19^{\text {th }}$ century by Mahmud Raif Efendi's, that is, Tableau Des Nouveaux Reglements De L'Empire Ottoman. This book is almost exclusively a conglomeration of various books and embassy reports. Only later, particularly during the Tanzimat Era, did some original books on geography begin to appear. It was also during this period that a large number of books on physical geography were being translated, particularly from English (Türkay, 1959, p. 5).

As a matter of fact, Ottomans were gradually embracing western sciences towards the end of the $19^{\text {th }}$ century. Quotations began to appear from some fundamental books, whereby the Turkish printing press was revived in 1874 . Whether in the form of quotations from European books or in the form of one-to-one translation, the most popular books were those offering practical information. In the meantime, the value of European books began to gain importance once again in relation to Ottoman ones. However, European books increased in number and had more impact on the east due to the fact that Ottoman books were being continually defamed by the books written on culture in Europe. Therefore, no fruitful exchange of ideas could be achieved between the east and the west. On the whole, the impact of a situation that affected the whole east was felt among the Ottoman Turks far more visibly (Taeschner, 1926, p. 313).

Taeschner argues that eastern and western civilizations of the $19^{\text {th }}$ century were close to getting into a conflict with each other, which could ignite a revolution anytime soon. In explaining the two different attitudes Ottoman intellectuals had developed towards the western civilization, Taeschner says the difference between east and west was so clear that there was an urgent need for a revolution. In the early 1800 s, remarkable changes were taking place in the way Ottomans viewed the world. Meanwhile, loyalty to medieval Islamic civilization was being consciously kept fresh. That is to say, there was no intention to break up with the past whatever the cost. However, this attitude was slowly being abandoned by the beginning of the $19^{\text {th }}$ century. In the opinion of Taeschner, while the western influence upon Ottoman intellectuals had turned out advantageous in some fields, it caused interruption in some others.

Ottomans of this century developed such an unconventional attitude towards westernization that they even began to frown upon Evliya Çelebi due to their fascination with Europeanization. Therefore, it is hardly surprising that Ottoman geography books were adversely affected by this dramatic change. They had already been exposed to western influences before an investigation based on ancient traditional books could even be made. Furthermore, the impact of western works literally came to a full stop in many fields.

Under the influence of this chaotic viewpoint, a large number of precious works of the east were being tagged as old-fashioned due to the ever-increasing predominance of the west. Understandably, the $19^{\text {th }}$ century Ottomans were overwhelmed by the scientific developments in Europe. Due to their conscious obsession with Europeanisation in all respects, they began to give less and less importance to earlier oriental works. In summarizing this frame of mind, Taeschner says "An Ottoman intellectual who was obsessed with Europeanisation was simply frowning upon Evliya Çelebi” (Taeschner, 1926, p. 271).

In contrast, another group was preoccupied with importing the potentially powerful culture of Europe. In their opinion, it was possible to take advantage of the benefits of European civilisation without having to break up with their own. Therefore, a way for absolute submission to Europe was being gradually paved due to an obsession with embracing European civilisation. A large portion of the Orient civilisation was breaking up with real life and gravitating towards Occidentalism. However, this trend was not cherished by any religious movement (Taeschner, 1926, p. 314).

Apart from Franz Taeschner, whose article is the focus of the present study, German orientalists, such as Franz Babinger, Helmut Ritter, Walter Ruben and Paul Kahle (who conducted remarkable investigations into the Turkish world and culture beginning from the early period of the $20^{\text {th }}$ century), draw our attention with their meticulous studies. While Taeschner is mainly known for his extensive studies like Anadolu Yollar (Roads of Anatolia), Ahilik Teşkilatı (Ahi Community) and Fütüvvet (The rules and regulations of Turkish-Islamic guild), he is also famous for his research into and works on subjects as diverse as medieval Persia and Ottoman resources and Turkish culture. Therefore, he is acknowledged as a researcher competent in the mentality of Oriental and Ottoman geography.

\section{CONCLUSION}

Taking everything mentioned above into account, we can assume that, beginning with the $19^{\text {th }}$ century, the Ottoman mentality of science was overwhelmingly exposed to and influenced by that of Europe. While the author talks about the influences of the method mentality upon such disciplines as history, literature and geography, he expressed his opinion that the literary books written after the $19^{\text {th }}$ century should not be 
considered Ottoman works but rather be considered as European works written in Ottoman Turkish. He even goes so far as to claim that even modern Turkish literary works could be placed in this category, given that these works lack the merits of scientific tradition.

In Taeschner's opinion, historiography is placed in a different category. A European-based perspective on historiography was being very skilfully introduced to the areas where the Ottoman historiography was prevailing. Interestingly, Ottomans first began to adopt a European perspective of scientific methods in the discipline of history. Therefore, instead of the conventional style of writing of history, historical investigations began to find their way in. However, the author does not mention which historians or books should be taken into consideration. Moreover, he does not support this claim with any examples or evidence, probably because his article was not about history in particular, but about geography.

Finally, we witness the fact that Ottoman geography and literary books written in the $19^{\text {th }}$ century were heavily influenced by the European perspective of science. Beginning with this period, some Ottoman intellectuals began to move away from dealing with their traditional works while some others considered such a tendency an inferiority complex. This divided viewpoint of Ottoman intellectuals went on to affect the $20^{\text {th }}$ century Ottoman intellectuals as well. However, it is promising to see that Turkish intellectuals are finally breaking away from this influence, though they should first grow mature enough to fully appreciate and consistently evaluate traditional works. Only then will they be able to analyse differences and synthesize the similarities between works written with European scientific methods and those of traditional methods. Such a scientific maturity and ideation has a lot to do with seeing the unity between the geographical structure of the world and the cosmological structure of the universe. Such a paradigm can only be achieved with a drastic change in the perspective required not only for geography but also for all scientific disciplines.

Grant Support: Authors received no financial support for this work.

\section{REFERENCES}

Adıvar, A. A. (1982). Science in Ottoman Turks. İstanbul: Remzi Bookstore.

Ak, M. (1993). Geography. Islam Encyclopedia, İstanbul: Türkiye Diyanet Vakfi Publisher.

......., (2004). Ottoman geography studies. Türkiye Literature Research Magazine, Skin: 2, Number: 4, p.p. 163-211.

Çetin, E. (2014). Notes on Franz Taeschner's work on various ways in Anatolia. Tarih Okulu Magazine (TOD), Year: 7, Skin: (XVII), p.p. 321-343.

Evliya Çelebi. (1992). Seyahatname. (By: M. Emre Karaörs), İstanbul: Morpa Publisher.

Göçer, Z. (2006). The life and works of Franz Taeschner. Selçuk University Institute of Social Sciences, Department of History, Master Thesis, Konya.

Hedda, R. K. (2010). Franz Taeschner. Diyanet Íslam Ansiklopedia, Skin: 39, p. 369, Istanbul.

Orhonlu, C. (1964). Geography in the Ottomans in the $18^{\text {th }}$ century and Atlas of Ibrahim Hamdi of Bartın, Istanbul University History Magazine, Number: 19, Istanbul.

Önder, M. (1968). Franz Taeschner (8.9.1888-11.11.1967). Turkish Culture Magazine, Skin: 64, p.p. 261-262, Ankara.

Özkul, O. (2009). Ottoman ulema between tradition and innovation. Sakarya: Sakarya University Publisher.

Taeschner, F. (1926). Geography in the Ottomans. (Interpretation: Hamid Sâdî), Türkiyat Magazine, Skin: II, p.p. 271-314, Istanbul.

Türkay, C. (1959). Geography of Ottoman Turks. Istanbul: Maarif Publisher. 
